\title{
Repair of comminuted fracture of the lower patellar pole
}

\author{
Elsayed Ibraheem Elsayed Massoud, M.D.
}

Department of Orthopaedic, Sohag Teaching Hospital, General Organization for Teaching Hospitals and Institutes, Egypt

\begin{abstract}
BACKGROUND: Comminuted fracture of the lower patellar pole has characteristics of both patellar fracture and avulsion of the patellar tendon. Therefore, components of both injury types should be considered during treatment. None of the traditional techniques has proven sufficient alone. Currently described is technique that incorporates principles of osteosynthesis as well as repair of the patellar tendon.
\end{abstract}

METHODS: Total of 23 patients with comminuted fracture of the lower patellar pole were treated surgically and prospectively followed for 24 months.

RESULTS: All patients returned to pre-injury level of activities of daily living at average of fourth postoperative month. Average score on scale described by Böstman et al. was 28.1 points. All fractures united within average of 10 weeks. Patellar height was preserved. Only 4 patients, all post-menopausal, demonstrated increase in degenerative changes in patellofemoral joint.

CONCLUSION: Successful osteosynthesis of the comminuted lower patellar pole using the present technique reduces potential need for partial patellectomy, and preserves original length of the extensor mechanism. Present technique allows for immediate full weight-bearing and early, extensive rehabilitation program.

Keywords: Extensor mechanism; fractured patella; inferior pole of the patella; patellar tendon; patellectomy.

\section{INTRODUCTION}

Progress in understanding mechanical function of extensor mechanism has rendered preservation of patellar dimensions mandatory. ${ }^{[1]}$ Retention of the fractured lower patellar pole signifies restoration of length of the extensor mechanism; however, no accepted technique has yet emerged. Of the widely used techniques, modified $A O$ tension band wiring requires large fragments suitable for fixation with Kirschner wire (Fig. I). Circumferential wiring allows for separation of fracture fragments due to soft tissue between wire and bone. ${ }^{[2]}$ Furthermore, it may strangle blood vessels in their peripatellar course. $^{[3]}$ Separate vertical wiring technique was first introduced by Yang and Byun, and several modifications have been made; ${ }^{[4-6]}$ however, complications have been reported. Basket plate was designed for osteosynthesis of the lower patellar

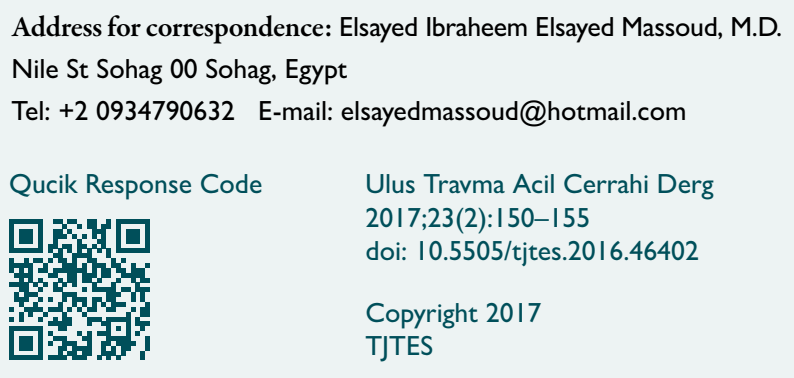

pole and has also been modified, ${ }^{[7,8]}$ but it failed to incorporate tiny fragments and to maintain patellar height simultaneously.

In comminuted fracture of the lower patellar pole, bundles of the patellar tendon are denuded of bony attachment. Therefore, this injury should be treated according to considerations of osteosynthesis as well as repair of the patellar tendons. Biomechanical study indicated that Magnusson wiring technique, in which wire loop is in direct contact with bone, allowed for better fixation of patellar fracture. ${ }^{[2]}$ In the same context, present author used transpatellar absorbable suture to reattach avulsed patellar tendon. ${ }^{[9]}$ It was hypothesized that combination of both Magnuson and Massoud techniques could reduce drawbacks of other traditional techniques for repair of comminuted lower patellar pole. In this study, nature of comminuted fracture of the lower patellar pole is examined, and combination technique for repair is presented with analysis of results.

\section{MATERIALS AND METHODS}

During period from April 2007 to April 2013, 23 patients who agreed to participate in prospective study were identified and managed for comminuted fracture of the lower patellar pole (Table I). The Sohag Teaching Hospital ethics committee approved the study. Most of the patients were female (78\%); mean age at time of operation was 53.4 years (range: 

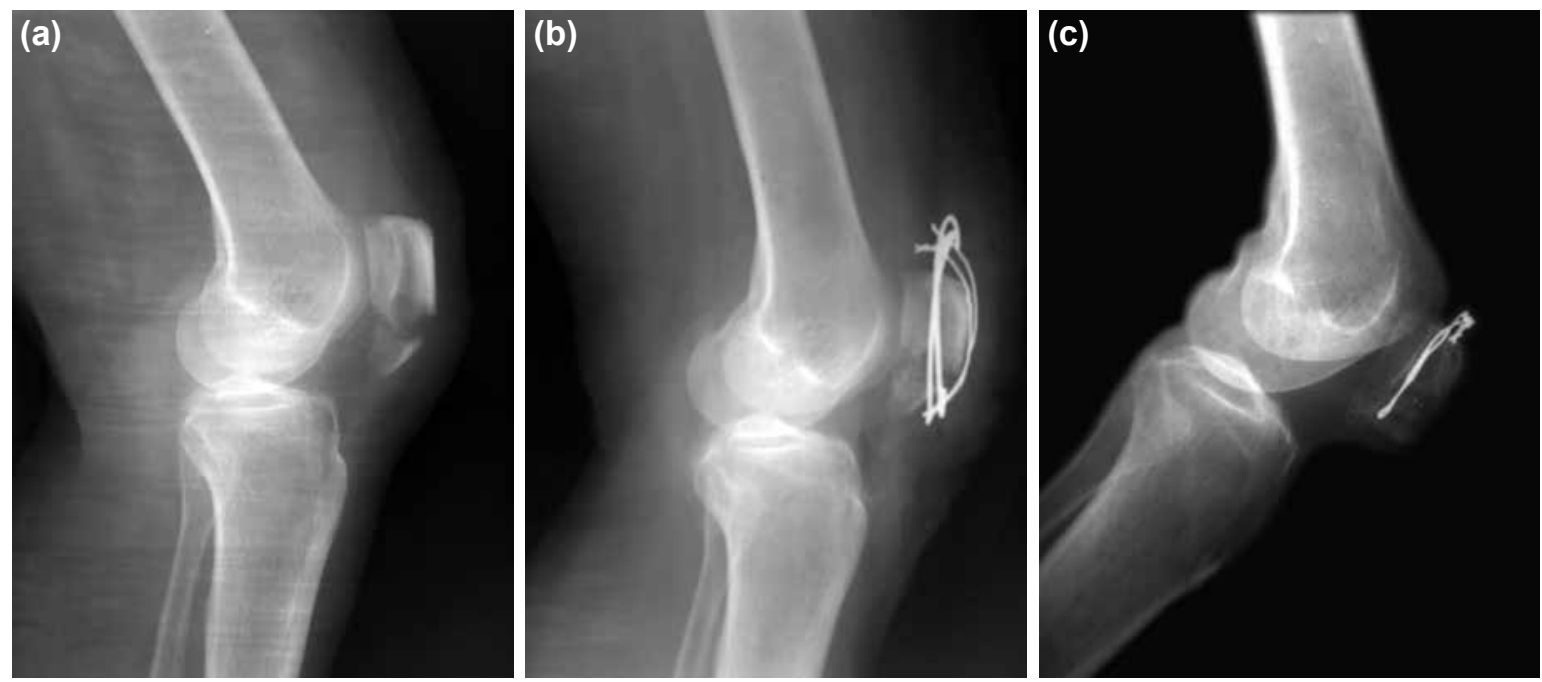

Figure 1. (a) Preoperative lateral radiograph of the right knee of 39-year-old male shows fracture of the lower patellar pole. Patient was treated with modified AO tension band wiring; (b) Slippage of Kirschner wires was observed and presently described technique was applied; (c) Lateral radiograph taken 4 weeks postoperatively shows migration of wire loop to below main fracture line.

17-73 years). They presented with recent history of trauma and inability to bear weight. Physical signs, such as swelling and infrequently, skin bruises, were observed. Tenderness, inability to elevate straight leg, and high proximal patellar pole compared with contralateral side were detected. Radiographic examination revealed comminuted fracture of lower pole of the patella. Common comorbidities were hepatitis $\mathrm{C}$ virus infection $(\mathrm{HCV})$ in $52 \%$ of the patients, diabetes mellitus in $30 \%$, and cerebral palsy in 2 young adults (Table I).

\section{Operative Technique}

Under spinal anesthesia and with tourniquet applied, patella was exposed through midline longitudinal incision extending from the upper patellar pole to point proximal to tibial tuberosity. Drill bit $3.2 \mathrm{~mm}$ in size was used to create 2 longitudinal tunnels between site of fracture and the upper patellar pole (Fig. 2a). Interwoven \#2 Vicryl sutures (Ethicon, Inc., Somerville, NJ, USA) were placed at proximal end of the patellar tendon just distal to osteotendinous junction and suture remnants were left in place. Interwoven sutures joined separated bundles of the patellar tendon to bundles still attached to bone fragments, converting them into integral units (Fig. 2a, b). Next, malleable stainless steel wire of $1 \mathrm{~mm}$ diameter was passed distally through mid-substance of a corner of
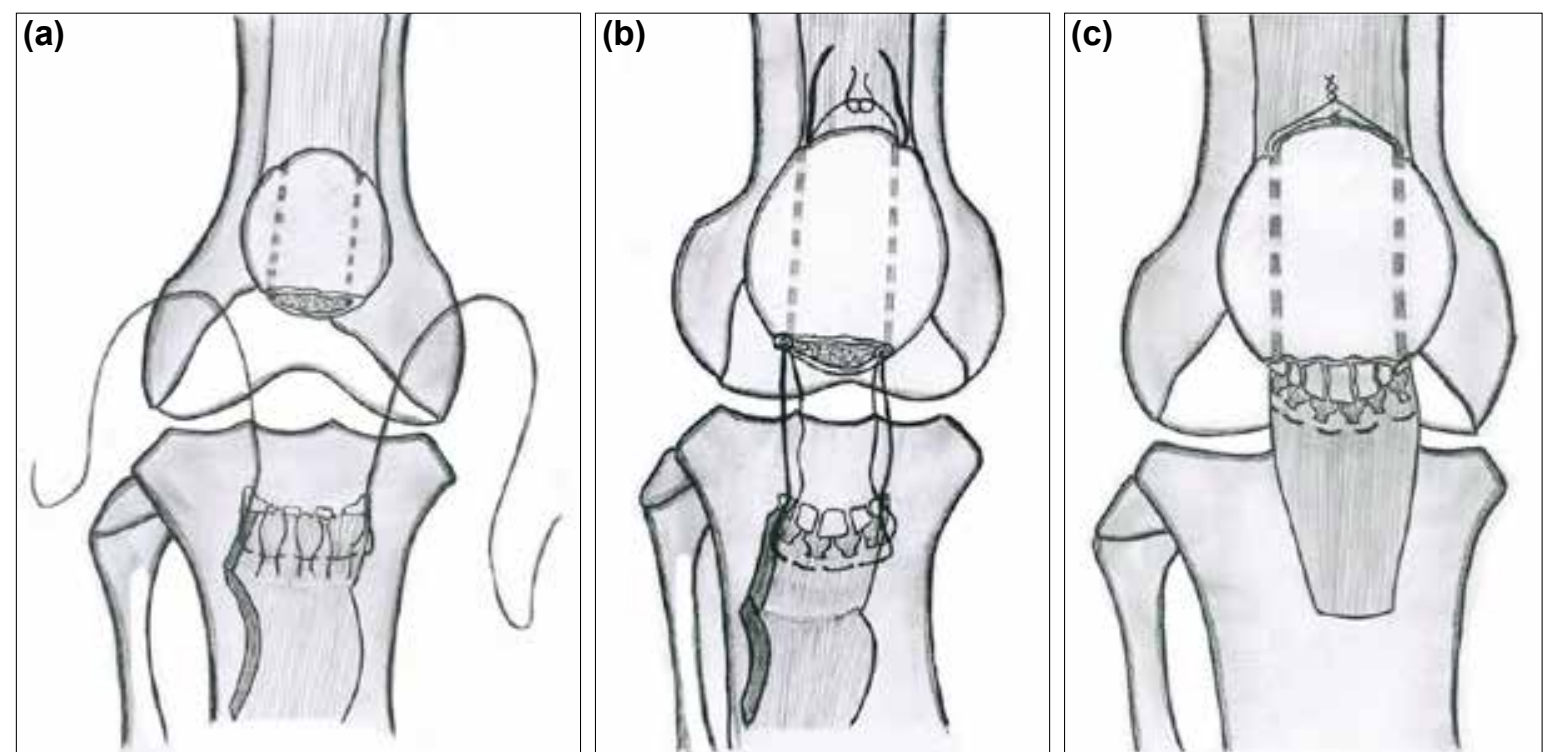

Figure 2. Drawing illustrates steps of repair of comminuted fracture of the lower patellar pole; (a) Interwoven absorbable sutures joining denuded bundles of the patellar tendon that attached to the bone fragments; (b) Cerclage wire passed through the patellar tendon, then with the Vicryl thread through transpatellar tunnels to upper patellar pole; (c) Final appearance after tying wire and thread. 
Table I. Pre and postoperative details of patients with comminuted lower patellar pole

\begin{tabular}{|c|c|c|c|c|c|c|c|c|c|}
\hline \multirow[t]{4}{*}{ Patient no } & \multicolumn{4}{|c|}{ Preoperative data } & \multicolumn{5}{|c|}{ Postoperative outcome } \\
\hline & \multirow{3}{*}{$\begin{array}{c}\text { Age } \\
\text { (years) }\end{array}$} & \multirow{3}{*}{ Sex } & \multirow{3}{*}{ Side } & \multirow{3}{*}{ Comorbidity } & \multirow{2}{*}{\multicolumn{2}{|c|}{$\frac{\text { Clinical outcome }}{\text { Böstman et al. scale }}$}} & \multicolumn{3}{|c|}{ Radiographic outcome } \\
\hline & & & & & & & \multirow{2}{*}{$\begin{array}{l}\text { Time to } \\
\text { union } \\
\text { (weeks) }\end{array}$} & \multirow{2}{*}{$\begin{array}{c}\text { A/B } \\
\text { ratio }\end{array}$} & \multirow{2}{*}{$\begin{array}{c}\text { P-F joint } \\
\text { (compared to } \\
\text { preoperative) }\end{array}$} \\
\hline & & & & & Points & Rating & & & \\
\hline I & 55 & Female & Left & $\mathrm{HCV}$ & 28 & Excellent & 10 & 0.80 & Similar \\
\hline 2 & 60 & Female & Right & $\mathrm{HCV}$ & 30 & Excellent & 10 & 0.87 & Similar \\
\hline 3 & 40 & Female & Left & DM & 30 & Excellent & 8 & 0.90 & Similar \\
\hline 4 & 45 & Female & Left & Irrelevant & 30 & Excellent & 8 & 0.85 & Similar \\
\hline 5 & 40 & Male & Left & HCV, DM & 23 & Good & 12 & 0.80 & Similar \\
\hline 6 & 65 & Female & Right & $\mathrm{HCV}$ & 30 & Excellent & 10 & 0.84 & Similar \\
\hline 7 & 17 & Male & Right & $\mathrm{CP}$ & 30 & Excellent & 8 & 0.92 & Similar \\
\hline 8 & 55 & Female & Right & Irrelevant & 28 & Excellent & 8 & 0.92 & Similar \\
\hline 9 & 68 & Female & Left & $\mathrm{HCV}$ & 27 & Good & 12 & 0.82 & Dissimilar \\
\hline 10 & 63 & Female & Left & Irrelevant & 30 & Excellent & 10 & 0.90 & Similar \\
\hline 11 & 53 & Female & Left & $\mathrm{HCV}$ & 30 & Excellent & 8 & 0.90 & Similar \\
\hline 12 & 72 & Female & Left & $\mathrm{HCV}$ & 21 & Good & 12 & 0.76 & Dissimilar \\
\hline 13 & 66 & Female & Left & DM & 30 & Excellent & 8 & 0.80 & Similar \\
\hline 14 & 74 & Female & Left & Irrelevant & 28 & Excellent & 10 & 0.74 & Similar \\
\hline 15 & 52 & Male & Left & DM & 30 & Excellent & 8 & 0.84 & Similar \\
\hline 16 & 21 & Male & Left & $\mathrm{CP}$ & 30 & Excellent & 8 & 0.88 & Similar \\
\hline 17 & $4 I$ & Female & Left & Irrelevant & 30 & Excellent & 8 & 0.88 & Similar \\
\hline 18 & 44 & Female & Right & $\mathrm{HCV}$ & 30 & Excellent & 10 & 0.82 & Similar \\
\hline 19 & 73 & Female & Left & Irrelevant & 28 & Excellent & 12 & 0.76 & Similar \\
\hline 20 & 70 & Female & Left & HCV, DM & 21 & Good & 16 & 0.70 & Dissimilar \\
\hline 21 & 39 & Male & Right & HCV, DM & 30 & Excellent & 10 & 0.92 & Similar \\
\hline 22 & 65 & Female & Left & $\mathrm{HCV}$ & 25 & Good & 12 & 0.82 & Dissimilar \\
\hline 23 & 50 & Female & Left & HCV, DM & 28 & Excellent & 8 & 0.80 & Similar \\
\hline
\end{tabular}

A/B ratio: Blackburne-Peel A/B ratio; CP: Cerebral palsy; DM: Diabetes mellitus; $H C V=$ Hepatitis C virus infection; $P-F$ joint: Patellofemoral joint.

the lower patellar pole to emerge just distal to Vicryl suture and was interwoven through the patellar tendon to emerge through other corner, as in Kessler's suture (Fig. 2b). Wire and thread were passed through tunnels to upper pole and tied while knee was extended (Fig. 2c). Stability of repair was tested with full flexion of knee. Excessive tightening of wire loop was avoided to nullify compression of comminuted fracture. Retinacular tears were repaired using \# I Vicryl suture, wound was closed, and Robert Jones bandage was applied for 2 weeks. ${ }^{[10]}$

\section{Postoperative Care}

Immediately after surgery, isometric quadriceps exercises were instituted and walking with full weight-bearing was allowed. At postoperative 2 weeks, bandage was removed and program of straight leg raise and active flexion exercises was initiated. At end of eighth week after surgery, vigorous program of straight leg raise with weights and active flexion exercises was implemented. Rehabilitation program continued until full range of knee motion and thigh girth compared with contralateral side was restored.

Follow-up examinations were carried out every other week for 12 weeks and then again at 4, 6, and 12 months postoperatively. After first year, patients were examined twice per year. Outcome was assessed with clinical and radiographic data at 24 months.

\section{Outcome Measures}

Function of the knee was evaluated using clinical grading scale of Böstman et al. ${ }^{\left[{ }^{\prime \prime}\right]}$ Evaluation involved completion of questionnaire regarding pain, work, assistance with walking, 
giving way, and stair climbing (maximum score: 18 points). Clinical evaluation included measurement of range of knee movement, thigh atrophy, and knee effusion (maximum score: 12 points). Overall score was rated excellent (30-28 points), good (27-20 points), or unsatisfactory ( $<20$ points). ${ }^{\left[{ }^{\prime \prime}\right]}$

Radiographs were examined for assessment of fracture healing, for patellofemoral degenerative changes compared with preoperative radiograph, and assessment of patellar height using Blackburne-Peel A/B ratio. ${ }^{[12]}$ Patella alta was diagnosed when $A / B$ ratio was $>1.06$. Patella baja was diagnosed when $A / B$ ratio was $<0.54$. Patella alta, patella baja, and increase in degenerative changes in the patellofemoral joint were considered unsatisfactory results. ${ }^{[9]}$ Fracture was defined as healed if fracture line was obliterated or bridged. Time to union was estimated from date of surgery to date of fracture healing. Nonunion was defined as progressive widening of fracture line with or without wire fragmentation. Proximal migration of wire loop to fracture line and displacement of distal pole were considered technical failure. Migration of wire through substance of distal pole without widening of fracture line was not considered complication (Fig. 3b).

\section{RESULTS}

At final follow-up, 18 patients were free of pain. However, 5 patients reported occasional pain with knee flexion or prolonged walking. Causes of pain were irritation of wire knot in suprapatellar area in 2 patients (Fig. Ic, 3b), and degenerative osteoarthritis in the patellofemoral joint in 3 patients. Pain in these patients persisted even after wire removal, and radiography revealed degenerative changes in patellofemoral joint. All patients returned to preoperative level of activities of daily living at average of 4 postoperative months. Patients who worked at home or outdoors before injury returned to work. Three patients reported knee sometimes giving way and dif-
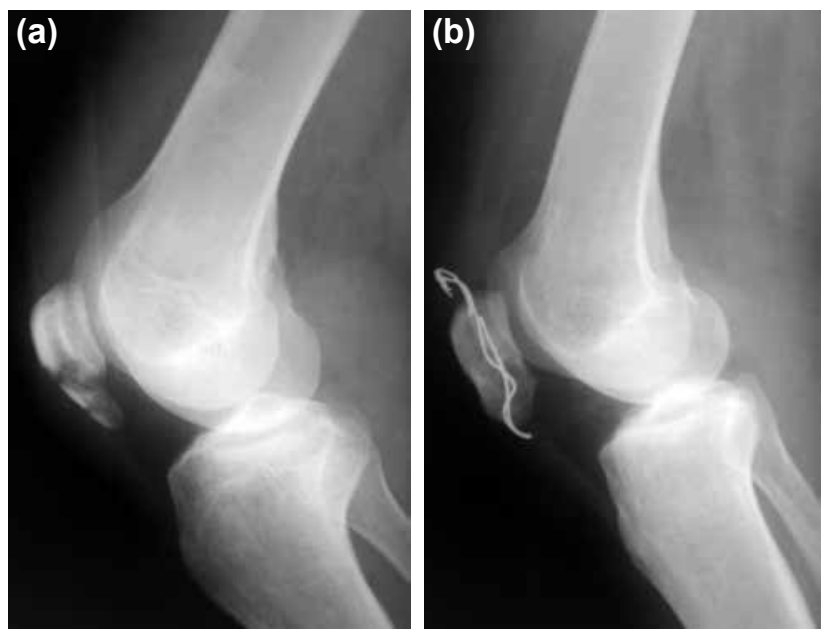

Figure 3. (a) Preoperative lateral radiograph of the left knee of 45-year-old female shows comminuted fracture of the lower patellar pole; (b) Lateral radiograph taken 1 year postoperatively shows healed fracture, preserved patellar height, and broken wire loop. ficulties with stair climbing. All patients had active full knee extension with $>120$ degree active knee flexion. Atrophy of thigh (range: 15-25 mm) was observed in 6 patients. According to clinical grading scale of Böstman et al., ${ }^{[1]} 18$ patients were classified as excellent and 5 as good (Table I). Mean Böstman et al. score was 28.1 points (range: $2 \mathrm{I}-30$ points).

\section{Radiographic Results}

All fractures united within average of 10 weeks (range: 8-16 weeks). Using Blackburne-Peel A/B ratio, ${ }^{[2]}$ patellar height averaged 0.84 (range: $0.70-0.92$ ). There was no report of patella alta or patella baja. Final outcome radiographs demonstrated similarity to preoperative patellofemoral joint in 19 patients. Four postmenopausal female patients had dissimilarity in form indicating increased degenerative changes (Table I). Overall radiographic outcome was satisfactory in 19 patients and unsatisfactory in 4 patients.

Proximal migration of wire loop through the lower patellar pole but distal to the main fracture line was seen in I patient at fourth postoperative week (Fig. Ic). At final followup, fracture had healed, patella had preserved normal height, no further migration was observed, and the patient reported excellent result.

Break of wire loop was observed in all patients during second year of follow-up period (Fig. 3b). By end of the second year, all wires had been removed.

\section{DISCUSSION}

Comminuted fracture of the lower patellar pole presents special situation. Definition of this injury determines appropriate technique for repair. However, traditional techniques have drawbacks and limitations. Improvement of nature of this injury through conversion of the bundles attached to the comminuted bone and the denuded bundles of the patellar tendon to integral units seems an attractive option.

Comminuted fracture of the lower patellar pole has been described as avulsion fracture. ${ }^{[8]}$ This means that injury has characteristics of fracture and avulsion of the patellar tendon. Absorbable interwoven sutures through the patellar tendon have been used to tie fragments together. ${ }^{[5,8]}$ In presently described technique, sutures were used to bind denuded tendon bundles to bundles that had bony attachments as well as to bring osteotendinous structure to its bed in main fragment. However, validity of absorbable suture for osteosynthesis was not tested widely. Therefore, Magnusson wire was also used for osteosynthesis (Fig. 2).

Forces that act at fracture site are either three-points bending with knee flexion or distraction force in extension. ${ }^{[2,13]}$ Carpenter et al. reported that wiring does not resist displacement at fracture site while knee is extended. ${ }^{[13]}$ However, Weber et al. reported that Magnusson wiring rigidly 
fixes fracture fragments through arc of motion of $90^{\circ}$ flexion through $10^{\circ}$, but from $10^{\circ}$ to $0^{\circ}$ there was minimal separation of fracture fragments. ${ }^{[2]}$ Even so, wide insertion of patellar retinaculum, ${ }^{[14]}$ widely distributes tensile stress of extensor mechanism as well. Thus, Weber et al. considered repair of the retinaculum to be most important stabilizing factor in less rigid repairs. ${ }^{[2]}$ Given minimum separation has occurred, Kenwright et al. reported in study of bone healing that small gaps and moderate axial interfragmentary movement are widely accepted as enhancing fracture healing. ${ }^{[15]}$ Furthermore, it has been found that strength of implant has special importance, particularly in non-cooperative patients. Rigid implant causes additional destruction of bone fragments and/or laceration of the patellar tendon, which renders restoration of patellar length and height almost impossible. Conversely, less rigid implant allows for implant failure before damage to bone or tendon; therefore, making re-osteosynthesis practicable. ${ }^{[7]}$

Separate vertical wiring technique has been used for fixation of the lower patellar pole. However, first reports were that technique was not suitable for comminuted fractures in which some bundles of the patellar tendon were separated from bony attachments. Furthermore, holding power of technique was not strong enough and failed to include small fragments. ${ }^{[4]}$ Song et al. suggested augmentation with cerclage wire. ${ }^{[5]}$ However, circumferential wiring has previously mentioned mechanical limitations and biological drawbacks. ${ }^{[2,3]}$ Although $\mathrm{Kim}$ et al. used 3 cannulated screws in proximal fragments to avoid anterior migration of wire, anterior displacement of the lower pole was reported. ${ }^{[6]}$ Basket plate is more advanced technique, and design seems suitable for osteosynthesis of lower pole fracture. However, Krkovic et al. noticed difficulties in retaining position of plate and preservation of patellar height when the longitudinal screws were placed in apex of the patella. Therefore, they suggested placement of screws outside insertion of the patellar tendon. ${ }^{[7]}$ To our knowledge, this modification has not yet been tested clinically. Kastelec and Veselko used absorbable interwoven sutures through the patellar tendon to avoid slippage of fragment between the hooks that push fibers of the patellar tendon apart. Even with this modification, they reported shortening of the patellar tendon in I of II patients in study. ${ }^{[8]}$

Immediate postoperative mobilization and early full weightbearing are among advantages of osteosynthesis. However, with use of separate vertical wiring technique, Kim et al. adopted long leg cast immobilization for 4 weeks and allowed full weight-bearing from eighth postoperative week. ${ }^{[6]}$ Song et al. used immobilization with brace for I month and allowed partial weight-bearing as of second week. ${ }^{[5]}$ Yang and Byun used brace and allowed partial weight-bearing at postoperative first month. ${ }^{[4]}$ Osteosynthesis using basket plate allows for full weight-bearing at sixth postoperative week. ${ }^{\left[{ }^{8]}\right.}$ With present technique, full weight-bearing was encouraged immediately after surgery. Robert Jones bandage ${ }^{[10]}$ was removed at end of second week.
Average Böstman clinical score for patients who underwent separate vertical wiring was 29.5 points in study conducted by Yang and Byun, ${ }^{[4]} 28.7$ points in Kim et al. study, ${ }^{[6]}$ and 28.I points in Song et al. study. ${ }^{[5]}$ With presently described technique, which was primarily concerned with comminuted fracture, mean Böstman score was excellent 28.I points.

In the present study, 4 postmenopausal female patients demonstrated advancement of degenerative changes in patellofemoral joint. It is notable that most of study patients are females (78\%) and common comorbidity was HCV (52\%); both of which are associated with reduced bone mineral density. ${ }^{[16]}$ These factors likely contributed to incidence of injury as well as results. Suboptimal vitamin D level is associated with incidence of knee osteoarthritis in postmenopausal females. ${ }^{[17]}$ Moreover, low vitamin D level influences structural progression of osteoarthritis, in addition to association with muscle weakness and increased pain. ${ }^{[18]}$

Present study is limited by lack of control group. Given rarity of this injury, it would require multicenter, randomized, controlled trial to compare relative merits of presently described technique with other methods.

\section{Conclusion}

Present study addressed characteristics of comminuted fracture of lower pole of the patella and described technique to manage components of injury separately. Successful osteosynthesis of severe comminution using present technique reduces potential need for partial patellectomy and preserves original length of extensor mechanism. Excellent results obtained open the way for immediate full weight-bearing and early, extensive rehabilitation program.

\section{Acknowledgement}

I would like to thank my daughter Sara Elsayed Ibraheem Massoud, because she has hand-painted the drawing that illustrates steps of repair of the comminuted fracture of the lower patellar pole.

\section{Conflict of interest: None declared.}

\section{REFERENCES}

1. Massoud EIE. Fractured patella in children: Preservation of the patellar dimensions. Dicle Med J 2012;39:467-73. Crossre

2. Weber MJ, Janecki CJ, McLeod P, Nelson CL, Thompson JA. Efficacy of various forms of fixation of transverse fractures of the patella.J Bone Joint Surg Am 1980;62:215-20. Crossre

3. Scapinelli R. Blood supply of the human patella. Its relation to ischaemic necrosis after fracture. J Bone Joint Surg Br 1967;49:563-70.

4. Yang KH, Byun YS. Separate vertical wiring for the fixation of comminuted fractures of the inferior pole of the patella. J Bone Joint Surg Br 2003;85:1155-60. Crossre

5. Song HK, Yoo JH, Byun YS, Yang KH. Separate vertical wiring for the fixation of comminuted fractures of the inferior pole of the patella. Yonsei 


\section{Med J 2014;55:785-91. Crossret}

6. Kim YM, Yang JY, Kim KC, Kang C, Joo YB, Lee WY, et al. Separate Vertical Wirings for the Extra-articular Fractures of the Distal Pole of the Patella. Knee Surg Relat Res 2011;23:220-6. Crossret

7. Krkovic M, Bombac D, Balazic M, Kosel F, Hribernik M, Senekovic V, et al. Modified pre-curved patellar basket plate, reconstruction of the proper length and position of the patellar ligament--a biomechanical analysis. Knee 2007;14:188-93. Crossre.

8. Kastelec M, Veselko M. Inferior patellar pole avulsion fractures: osteosynthesis compared with pole resection. J Bone Joint Surg Am 2004;86:696701. Crossref

9. Massoud EI. Repair of fresh patellar tendon rupture: tension regulation at the suture line. Int Orthop 2010;34:1153-8.

10. Brodell JD, Axon DL, Evarts CM. The Robert Jones bandage. J Bone Joint Surg Br 1986;68:776-9.

11. Böstman O, Kiviluoto O, Nirhamo J. Comminuted displaced fractures of the patella. Injury 1981;13:196-202. Crossre

12. Blackburne JS, Peel TE. A new method of measuring patellar height. J Bone Joint Surg Br 1977;59:241-2.
13. Carpenter JE, Kasman RA, Patel N, Lee ML, Goldstein SA. Biomechanical evaluation of current patella fracture fixation techniques. J Orthop Trauma 1997;11:351-6. Crossret

14. Starok M, Lenchik L, Trudell D, Resnick D. Normal patellar retinaculum: MR and sonographic imaging with cadaveric correlation. AJR Am J Roentgenol 1997;168:1493-9. Crossret

15. Kenwright J, Richardson JB, Cunningham JL, White SH, Goodship AE, Adams MA, et al. Axial movement and tibial fractures. A controlled randomised trial of treatment. J Bone Joint Surg Br. 1991;73:654-9.

16. Lo Re V 3rd, Volk J, Newcomb CW, Yang YX, Freeman CP, Hennessy $\mathrm{S}$, et al. Risk of hip fracture associated with hepatitis $\mathrm{C}$ virus infection and hepatitis $\mathrm{C} /$ human immunodeficiency virus coinfection. Hepatology 2012;56:1688-98. Crossre

17. Abu el Maaty MA, Hanafi RS, El Badawy S, Gad MZ. Association of suboptimal 25-hydroxyvitamin D levels with knee osteoarthritis incidence in post-menopausal Egyptian women. Rheumatol Int 2013;33:2903-7.

18. Felson DT, Niu J, Clancy M, Aliabadi P, Sack B, Guermazi A, et al. Low levels of vitamin $\mathrm{D}$ and worsening of knee osteoarthritis: results of two longitudinal studies. Arthritis Rheum 2007;56:129-36.

\section{ORIJINAL ÇALIŞMA - ÖZET}

\section{Patella distal ucu parçalı kırı̆̆ının onarımı Dr. Elsayed Ibraheem Elsayed Massoud}

Sohag Eğitim Hastanesi, Ortopedi Bölümü, Eğitim Hastaneleri ve Enstitüleri, Mısır

AMAÇ: Patella distal ucunun parçalı kırığı hem patella kırı̆̆ı hem de patella tendonu avülsiyonunun karakteristik özelliklerini taşır. Bu nedenle travmanın her iki bileşeni de tedavi sırasında düşünülmelidir. Ancak geleneksel tekniklerin herhangi biri mahzurları olmaksızın ayrı ayrı işe yaramaz. Osteosentez ve patella tendonunun eş zamanlı onarımını göz önüne alan bir teknik varsayımladık.

GEREÇ VE YÖNTEM: Patella distal ucu parçalıkırı̆̆ı olan 23 hasta cerrahi yöntemle tedavi edilmiş ve ileriye yönelik olarak 24 ay izlenmiştir. BULGULAR: Hastaların tümü ortalama ameliyat sonrası dördüncü ayda travma öncesi günlük aktivite düzeyine geri döndü. Böstman ve ark. skorlamasına göre hastalar ortalama 28 , I puan aldı. Kırıkların hepsi ortalama 10 haftada kaynadı. Patella yüksekliği muhafaza edilmişti, ancak dört hastada patellofemoral eklemde dejeneratif değişikliklerde artış görüldü.

TARTIŞMA: Bu tekniği kullanarak patella distal uç parçalı kırığında osteosentezin başarısı parsiyel patellektomi olma ihtimalini azaltmakta, böylece ekstensör mekanizmanın fizyolojik uzunlluğu korunmaktadır. Bu teknik hemen tam olarak ağılık taşımaya ve erken dönemde yoğun rehabilitasyon programının uygulanmasına yol açar.

Anahtar sözcükler: Alt pol; ekstensör mekanizma; kırık; patella; patella tendonu; patellektomi.

Ulus Travma Acil Cerrahi Derg 2017;23(2):I50-155 doi: 10.5505/tjtes.2016.46402 